Creeping Juniper. It differs in its greater height (1-1/2-12 metres), its habit as a more or less erect shrub or small tree with a single main trunk in contrast to the Creeping Juniper which is entirely prostrate with both the main stem and branches trailing along the ground. The Rocky Mountain Juniper's scale-leaves are also less pungent when crushed, and blunt to abruptly sharp-pointed but not as sharply spine-tipped as those of the Creeping Juniper. These two species apparently are quite closely related and purported hybrid types have often been reported where they coexist. ${ }^{3}$ Such intermediate forms, therefore, might possibly also be expected in southern Saskatchewan. They are characterized by a short more or less erect main stem (or trunk), diffusely branched, partially decumbent (i.e., branches spreading but upright towards tips) growth form, seldom reaching more than one metre in height, and have been named $J$. scopulorum var. patens Fassett or $J$. $X$. fassettii, Boivin. ${ }^{3} 1$ These should at least be looked for in southern Saskatchewan.
In the key above, numbers in parentheses are extremes beyond normal range.

'BOIVIN, B. 1967. Flora of the Prairie Provinces, Part I. Provancheria 2. Mem. I'Herb. LouisMarie, Fac. d'Agric., Univ. Laval, Quebec City, Que.: pp. 37-38

${ }^{2}$ HARMS, V. L. 1973. Native conifers of Saskatchewan. Blue Jay 31(4):210-214.

"HITCHCOCK, C. L., A. CRONQUIST, and M. OWNBEY. 1969. Vascular plants of the Pacific Northwest. Part 1: Vascular Cryptogams, Gymnosperms, and Monocotyledons. University of Washington Press, Seattle; pp. 105-109.

${ }^{4}$ KUIJT, J and J. A. TROFYMOW. 1975. Range extensions of two rare Alberta shrubs. Blue Jay 33(2): $96-98$

"LITTLE, E. L. 1971. Atlas of United States trees. Vol. I Conifers and Important Hardwoods. Miscellaneous Publication No. 1146, Forest Service, U.S. Dept. of Agriculture, Washington, D.C. (Maps 30-W and 30-N).

${ }^{6}$ MOSS, E. H. 1959. Flora of Alberta, University of Toronto Press: p. 35.

'SMITH, W. W. and C. A. WALLIS. 1976. Extralimital occurence of Rocky Mountain Juniper in southeastern Alberta. Blue Jay 34(2): 67-68.

"STEVENS, O. A. 1952. Handbook of North Dakota plants. North Dakota Agricultural College, Fargo; p. 45.

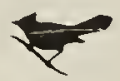

\title{
BIRD PREDATION ON THE YELLOW-HEADED SPRUCE SAWFLY, WITH NOTES ON THE LARCH SAWFLY
}

WAYNE C. WEBER, Department of Zoology, Mississippi State University, Mississippi State, Mississippi 39762

The yellow-head spruce sawfly (Pikonema alaskensis) is a defoliating insect (Order Hymenoptera, Family Tenthredinidae), found from Alaska and British Columbia to New Brunswick and Maine. Its larvae attack the needles of several species of spruces. ${ }^{2}$ Full-grown larvae are about 0.75 in- ches long, with a chestnut-brown head and a yellowish-green body with darker lengthwise grayish-green stripes (Fig. 1). Infestations rarely occur in closed forest but are usually confined to small ornamental spruces or plantations of young trees. However, they may cause the complete 


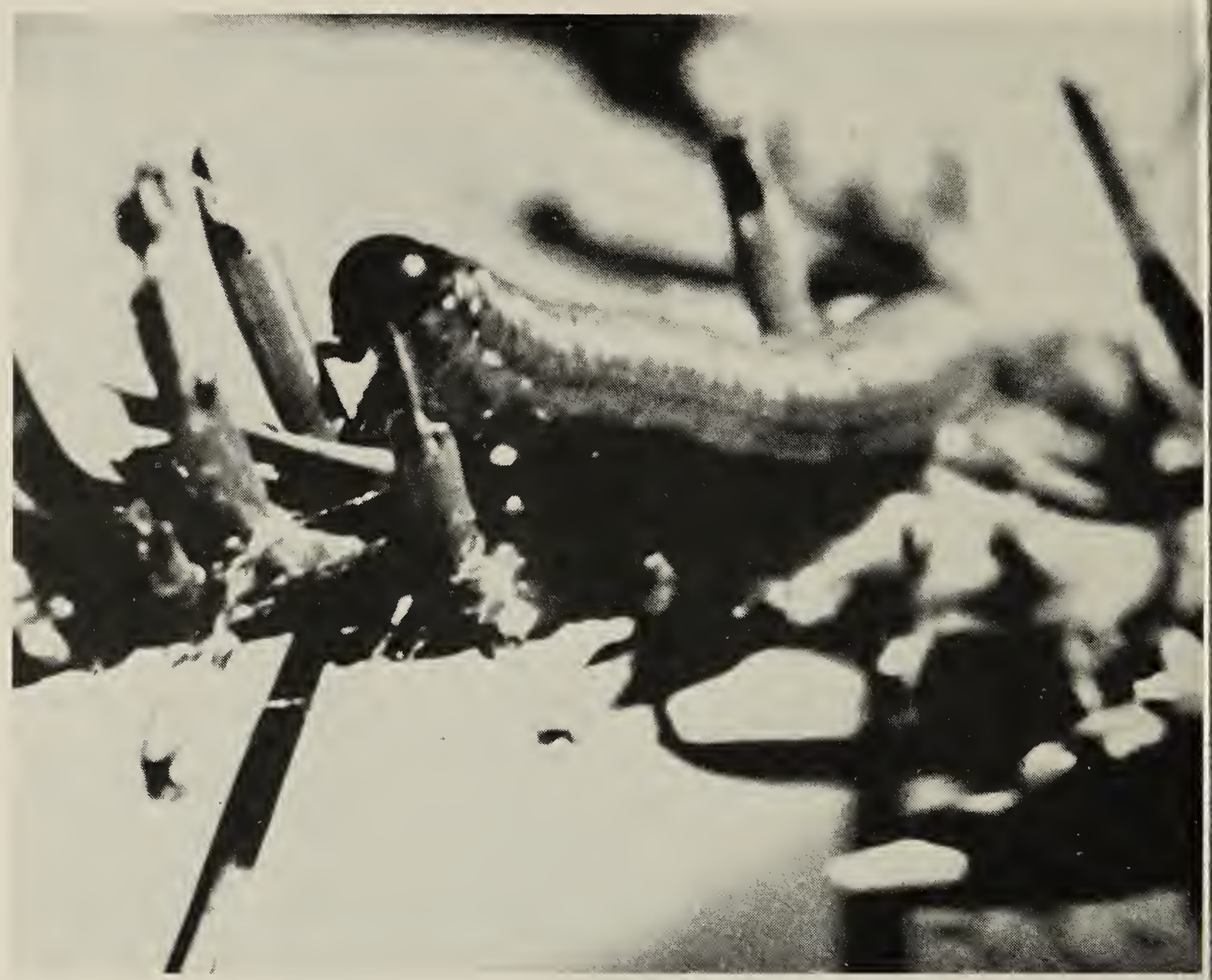

Figure 1. Larva of yellow-headed spruce sawfly. Roger Eddy (Courtesy Parks Canada).

defoliation and eventually the death of many trees. In 1972, I observed a small outbreak of spruce sawflies in Elk Island National Park, about 25 miles east of Edmonton, Alberta, and noted especially the activities of avian predators of the larvae.

The life history of the sawfly has been reviewed by Nash. ${ }^{4}$ The winter is spent underground in a cocoon. Adults emerge in late spring, and the females cut shallow slits in spruce needles, in which the eggs are deposited. In 6 to 8 days, the larvae hatch and begin to feed on the needles for a feeding period that lasts from 30 to 40 days. Finally the larvae drop to the ground, burrow into the soil, and spin a cocoon. The sawfly larvae appear to prefer new-growth needles for feeding; thus the tops of trees and tips of branches are defoliated first. A stand, once infested, is often defoliated several years in succession; this increases the chances that the trees will be killed.

In Elk Island National Park, the sawfly outbreak was mainly confined to ornamental plantings of white spruce (Picea glauca) in parking lots near Sandy Beach, on the east side of Astotin Lake. Most of the trees were 4 to 12 feet tall. In some plantings, many trees were largely or completely defoliated (Fig. 2), but in other areas the damage was light. The outbreak was first noticed in 1971 (Chief Park Warden V. R. Jones, pers. comm.), but was more severe in 1972. In 1972, damage was first evident in late June; I made observations on bird predation between 15 and 22 July.

The main purpose of my observations was to roughly determine the extent of bird predation on yellowheaded spruce sawfly larvae; I could find no previous accounts of birds preying on this species. I maintained a continuous watch on a stand of in- 
fested spruces from 09:00 to 11:00 on July $15,09: 00$ to $11: 00$ on July 16 , and $08: 30$ to $09: 50$ on July 22 . Four bird species definitely ate spruce sawfly larvae, and five other species foraged in or beneath the spruces and were suspected of eating larvae.

\section{Known Sawfly Predators}

PURPLE FINCH: This species was the most persistent and most voracious predator of sawfly larvae. A group of four Purple Finches, including two adult males, spent considerable time feeding on larvae on each day of observation. They hunted larvae for at least 59 minutes out of the total of 320 minutes I spent watching the spruces on July 15,16 , and 22 . The finches hunted larvae systematically, all four spending several minutes in one tree and then moving to another. They were never seen foraging other than in spruce trees, and may have fed almost exclusively on sawfly larvae during the study period. Because of the birds' rapid movements while foraging, I could not count the number of insects eaten but I estimated the consumption rate at perhaps five larvae per minute.

Chipping Sparrow: At least one adult male and two fledglings were in the spruces throughout the observation period. The male ate some sawfly larvae, but spent most of his time singing. The fledglings were seen hunting larvae several times, but appeared to receive most of their food from the adult. Sawfly larvae probably made up a large part of the Chipping Sparrows' diet. The sparrows spent nearly all their time in the spruces, and, unlike the Purple Finches, had probably nested there.

American Robin: On July 22, three or four of a group of 10 juveniles spent about 35 mintues in the infested spruces, eating sawfly larvae: the rest of the birds foraged on the ground. Also, two Robins fed beneath the spruces on July 16, and may have picked up fallen larvae.

Northern Oriole: A female or juvenile spent 2 minutes feeding on sawflies on July 16 . On the 15 th, an adult male, perched in an aspen among the spruces, ate an insect larva which may have been a sawfly.

\section{Suspected Sawfly Predators}

Common Grackle: A family group of six foraged beneath the spruces for a short time on July 22 , and two of them perched briefly in the trees and appeared to pick off a few larvae. Two Grackles also foraged beneath the trees on July 16.

Clay-Colored Sparrow: At least one adult male and one fledgling were present. They were not seen actually feeding on sawflies, but probably did so, as they spent nearly all their time in the spruces.

Three other species (Common Flicker, Black-billed Magpie, and Red-winged Blackbird) were seen foraging on the ground beneath the spruces, and may have picked up fallen larvae, but did not forage in the trees themselves.

\section{Larch Sawflies}

The Larch sawfly (Pristophora erichsonii), unlike the yellow-headed spruce sawfly, is a pest of considerable economic importance. Its larvae feed on the foliage of tamarack (Larix laricina), and may cause total defoliation and extensive tree mortality over large areas. During my observations on yellow-headed spruce sawflies in Elk Island Park, I noted larch sawfly larvae in a number of tamarack stands, and attempted to see if any bird predation on larch sawflies occurred. Two large tamaracks near Sandy Beach, near the infested spruce stands, had large numbers of larch sawfly larvae and were badly defoliated. Several other tamarack stands, mainly near the North Gate of the park, were visited on July 15,16 , 18 , and 22: sawfly larvae were present in some stands but none was severely defoliated. Although I spent several hours looking for bird predation on larch sawflies, I saw none.

Bird predation on larch sawflies has been thoroughly studied in Manitoba where stomach contents of 54 bird species were collected in infested tamarack stands.' Many species 


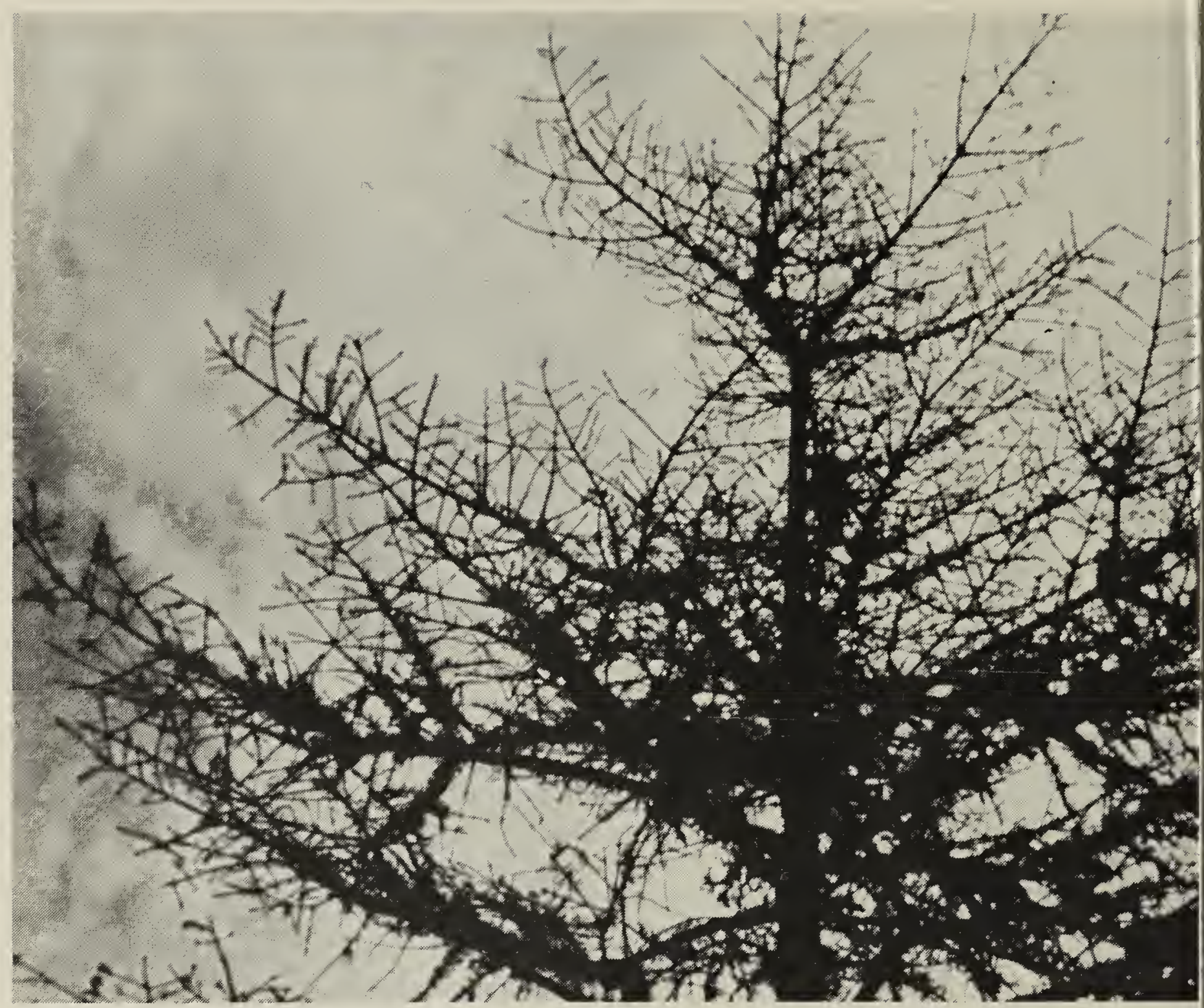

Figure 2. Young white spruce near Sandy Beach, Elk Island National Park, showing defoliation caused by sawfly larvae.

preferred adult sawflies to larvae. In a severely-infested tamarack stand, it was calculated that birds could remove only $0.5 \%$ of the larvae and $6 \%$ of adults; however, in a stand with a moderate sawfly density, the corresponding figures were $6 \%$ of larvae and $65 \%$ of adults.

Interestingly, the 3 species I observed most often feeding on spruce sawflies - Purple Finch, Chipping Sparrow, and American Robin - were also among the most important predators of larch sawflies in the Manitoba study, together accounting for $50.3 \%$ predation on larvae.'

The results of a number of studies of bird predation on defoliating insects support the general conclusion that predation by birds may have little effect in checking insect numbers when other factors, such as favourable weather, permit the development of an outbreak.' 3 However, when insect densities are low, birds may play an important role in limiting their populations.

\section{Control Measures for Spruce Sawflies}

In 1972 outbreak of yellow-headed spruce sawflies in Elk Island National Park, because of the small area affected, control measures against the sawflies were not necessary. However, if control of an outbreak is desired, the best approach is probably to apply an insecticide such as Malathion, which has a high toxicity to insects but a very low toxicity to birds and mammals." It should be applied when the larvae are young. Because the sawflies usually do not disperse far, it is likely that one thorough spraying at the proper time would protect the trees for several years. 


\section{Acknowledgments:}

These observations were made while I was employed as a Seasonal Naturalist with Parks Canada. W. Jack Schick, Chief Park Naturalist of Elk Island National Park, suggested that I observe the sawflies. Roger Eddy, former Park Warden, photographed the sawfly larvae. For comments on the manuscript, I thank W. Jack Schick and Jerome A. Jackson.

'BUCKNER, C. H. and W. J. TURNOCK. 1965 Avian predation on the larch sawfly, Pristophora erichsonii (Htg.), (Hymenoptera: Tenthredinidae). Ecology 46: 223-236.
${ }^{2}$ GRAIGHEAD, F. C. 1950. Insect enemies of eastern forests. U.S. Dept. Agr., Misc. Publ. 657.

${ }^{3 M O R R I S, ~ R . ~ F ., ~ W . ~ F . ~ C H E S H I R E, ~ C . ~ A . ~}$ MILLER, and D. G. MOTT. 1958. The numerical response of avian and mammalian predators during a gradation of the spruce budworm. Ecology 39: 487-494.

${ }^{4}$ NASH, R. W. 1939. The yellow-headed spruce sawfly in Maine. J. Econ. Entomol. 32: 330-334.

"WHITE-STEVENS, R. (Ed.). 1971. Pesticides in the environment, Vol. 1, Part I. Marcel Dekker Inc., New York.

\section{FISH-CATCHING MUSKRAT}

\section{DICK DEKKER, 3819-112A Street, Edmonton, Alberta.}

On May 30, 1976, I was quietly sitting on the Ducks Unlimited dam at Beaverhill Lake, Alberta when a muskrat appeared. It swam up from the southeast slough and headed for a small island, wedged in between the washed-out cement foundations of the eastern wing of the dam. Just before reaching the sandy shore, the rat dived and emerged with what looked like a small fish. When it dived again and came up with a similar food item, I kept the 10-power glasses focussed on the animal. It climbed on land about 20 meters away from me. To my surprise, its meal was indeed a fish, likely a stickleback that abounds in the lake. During the next 30 minutes, the muskrat caught and ate 11 more. After a spell of grooming, it dived and captured an additional nine.

The method of transporting and eating these fish was the same throughout. Upon emerging from each dive, the fish was held sideways in the rat's mouth. On land, the animal transferred the fish to its front feet. At this point the fish often flopped vigorously. The tail was invariably held upward, and the rat consumed the fish like a monkey would eat a banana, biting off chunks from the tail on down. When finished, the rat licked its front paws for a few moments before re-entering the water. Its dives lasted from 3 to 15 seconds. It took 15 to 25 seconds to eat a fish.

Finally, before swimming away to the slough, the rat climbed onto the bank of the islet and cut two mouthfuls of green grass. They were carried down and deposited in the water, before being eaten for dessert.

In the literature available to me, I found the following information on the food of the muskrat. Soper mentions only juicy plants." Murie writes that the muskrat is not entirely vegetarian and may feed on clams and mollusks. ${ }^{2}$ Other than plants, Banfield lists freshwater mussels, small turtles, frogs, salamanders and slow-moving catfish. ${ }^{\prime}$

'BANFIELD, A. W. F., 1974. The mamrnals of Canada. Univ. Toronto Press, Toronto. 438 p.

${ }^{2}$ MURIE, O. J., 1954. A field guide to animal tracks. Houghton Miffin, Boston.

:SOPER, J. D., 1964. The marnmals of Alberta. Queen's Printer, Edmonton. 402 p. 